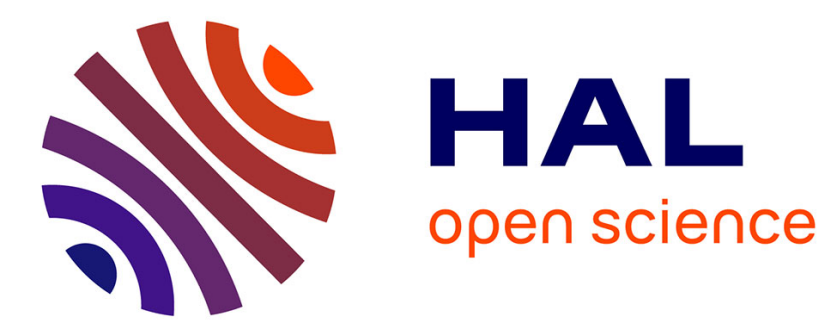

\title{
Nuclear demagnetization of PrS and PrNi5
}

Ch. Buchal, K.J. Fischer, M. Kubota, R.M. Mueller, F. Pobell

\section{To cite this version:}

Ch. Buchal, K.J. Fischer, M. Kubota, R.M. Mueller, F. Pobell. Nuclear demagnetization of $\operatorname{PrS}$ and PrNi5. Journal de Physique Lettres, 1978, 39 (23), pp.457-458. 10.1051/jphyslet:019780039023045700 . jpa-00231543

\section{HAL Id: jpa-00231543 https://hal.science/jpa-00231543}

Submitted on 1 Jan 1978

HAL is a multi-disciplinary open access archive for the deposit and dissemination of scientific research documents, whether they are published or not. The documents may come from teaching and research institutions in France or abroad, or from public or private research centers.
L'archive ouverte pluridisciplinaire HAL, est destinée au dépôt et à la diffusion de documents scientifiques de niveau recherche, publiés ou non, émanant des établissements d'enseignement et de recherche français ou étrangers, des laboratoires publics ou privés. 


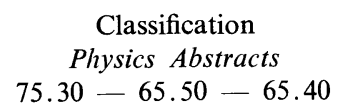

\title{
NUCLEAR DEMAGNETIZATION OF PrS AND $\operatorname{PrNi}_{5}\left({ }^{*}\right)$
}

\author{
Ch. BUCHAL, K. J. FISCHER, M. KUBOTA, R. M. MUELLER and F. POBELL \\ Inst. f. Festkörperforschung, Kernforschungsanlage Jülich, D-5170 Jülich, W.-Germany
}

(Reçu le 11 août 1978, accepté le 12 octobre 1978)

\begin{abstract}
Résumé. - Nous avons désaimanté les composés $\operatorname{PrS}$ et $\mathrm{PrNi}_{5}$ dont le paramagnétisme de Van Vleck est augmenté par les couplages hyperfins. Des températures finales de $0,72 \mathrm{mK}(\operatorname{PrS})$ et de $0,55 \mathrm{mK}\left(\mathrm{PrNi}_{5}\right)$ ont été mesurées au moyen d'un thermomètre à fil de platine NMR. On a mesuré l'entropie nucléaire de PrS dans un champ de $75 \mathrm{mT}$. On s'attend à des températures finales plus basses pour PrS avec un contact thermique amélioré.
\end{abstract}

\begin{abstract}
We have demagnetized the hyperfine enhanced Van Vleck paramagnets PrS and $\mathrm{PrNi}_{5}$. End temperatures of $0.72 \mathrm{mK}(\mathrm{PrS})$, and $0.55 \mathrm{mK}\left(\mathrm{PrNi}_{5}\right)$ were measured by a Pt-wire NMR thermometer. The nuclear entropy of $\operatorname{PrS}$ in a field of $75 \mathrm{mT}$ has been measured. With improved thermal contact lower end temperatures are expected for PrS.
\end{abstract}

In the process of testing various hyperfine enhanced Van Vleck paramagnets as nuclear refrigerants for our double-stage nuclear demagnetization apparatus [1], we have investigated $\operatorname{PrS}$ and $\mathrm{PrNi}_{5}$. The latter had already been successfully used for nuclear cooling by Andres and coworkers [2], who have obtained end temperatures at around $0.8 \mathrm{mK}$, starting from $17 \mathrm{mK}$ and 2.3 T. $\mathrm{PrNi}_{5}$ has a hyperfine enhancement factor of 14.3 and an anticipated electron-nuclear ordering temperature of $0.57 \mathrm{mK}$ [2]. No ultralow temperature data have been reported for PrS. From magnetic and specific heat measurements at $T>1.3 \mathrm{~K}$, an enhancement factor of 5.8 has been determined and a cooperative nuclear ordering at a temperature below $0.3 \mathrm{mK}$ has been predicted [3].

For our experiments, $25.7 \mathrm{~g}$ of $\mathrm{PrNi}_{5}$, and $18.1 \mathrm{~g}$ of PrS have been used. The $\mathrm{PrNi}_{5}$ sample has been prepared as a rod of $0.65 \mathrm{~cm}$ diameter by arc melting at Ames Laboratory [4]. Its resistance ratio was 28. For the production of PrS samples, we pre-reacted the appropriate ratio of Pr-metal (from Ames Laboratory) and pure sulphur in a quartz ampoule writi : wating to $950^{\circ} \mathrm{C}$. The inhomogeneous reaction product was filled under argon atmosphere into a tungsten ampoule which was sealed by electron beam welding. Within 10 minutes the ampoule was brought to $2440{ }^{\circ} \mathrm{C}$, the melting point of PrS. The melt was overheated

$\left({ }^{*}\right)$ This paper has been presented at the LT 15 Conference as a post-deadline paper. for 1 hour at $2550^{\circ} \mathrm{C}$, cooled in a temperature gradient within 3 hours to $2300^{\circ} \mathrm{C}$, and then faster to room temperature. The polycrystalline sample of $1.2 \mathrm{~cm}$ diameter had grains up to $0.1 \mathrm{~cm}^{3}$ within the first frozen parts. The PrS exhibits a dark golden colour, is single phase and very brittle. Stoichiometric and metal rich samples do not adhere to the tungsten walls, whereas sulphur rich samples are not removable from the crucible without cracking.

For the demagnetization experiments, the samples have been soldered to 50 strands of $0.03 \mathrm{~cm}$ diam. $\mathrm{Cu}$ wires linking them to our Pt-wire NMR thermometer [5] and via a superconducting heat switch [6] to the pre-cooling mixing chamber. Whereas soft soldering to $\mathrm{PrNi}_{5}$ is no problem, making thermal contact to PrS proved to be a substantial obstacle. Eventually, $\operatorname{PrNi}_{5}$ turned out to be a suitable solder for PrS. We soldered the PrS by induction heating in vacuum. The sample itself was used as a crucible by spark cutting a central hole into it. After melting inside this hole, $\mathrm{PrNi}_{5}$ makes good contact to $\mathrm{PrS}$. Then a second hole was cut into the $\mathrm{PrNi}_{5}$ (remaining amount of $0.79 \mathrm{~g} \mathrm{PrNi}_{5}$ ) and to this material we soldered the copper wires.

Starting conditions for the demagnetizations were $H_{\mathrm{i}}=8 \mathrm{~T}$, and $T_{\mathrm{i}}$ between $17 \mathrm{mK}$ and $36 \mathrm{mK}$. For both compounds a linear relation between the final temperature $T_{\mathrm{f}}$ and final fields $H_{\mathrm{f}}$ was observed down to about $3 \mathrm{mK}$. We consider this as a support of the reliable performance of our $\mathrm{Pt}$ thermometer, and of 
the minimal entropy losses during demagnetizations down to $3 \mathrm{mK}$. Deviations from linearity between $H_{\mathrm{f}}$ and $T_{\mathrm{f}}$ are only expected at lower temperatures due to the onset magnetic ordering below $1 \mathrm{mK}[2,3]$. The final temperature observed with $\mathrm{PrNi}_{5}$ in a field of $0.015 \mathrm{~T}$ was $0.55 \mathrm{mK}(+5 \%)$. This temperature is lower than the minimum temperature of $0.8 \mathrm{mK}$ previously observed for $\operatorname{PrNi}_{5}$, but is consistent with a calculated ordering temperature of $0.57 \mathrm{mK}$ [2]. The observed relaxation times of the $\mathrm{Pt}-\mathrm{Cu}-\mathrm{PrNi}_{5}$ system were less than $1 \mathrm{~min}$. at $T>2 \mathrm{mK}$; they increased to $5 \mathrm{~min}$. at $1 \mathrm{mK}$, and to $30 \mathrm{~min}$. at our lowest temperatures ; this relaxation results from the low thermal conductivity of $\mathrm{PrNi}_{5}$ and its high specific heat.

Taking data on PrS was strongly hindered by much longer relaxation times; they increased to $8 \mathrm{~h}$. around $1 \mathrm{mK}$. We measured the effective thermal coupling of the $\mathrm{Cu}$-wires to the $\mathrm{PrS}$ and found a conductance proportional to $T$, being $2 \mathrm{nW} / \mathrm{mK}$ at $3 \mathrm{mK}$. As the heatleak into the set-up is measured to be $0.5 \pm 0.1 \mathrm{nW}$, the minimum temperature at the Pt-thermometer is expected to be $0.75 \mathrm{mK}$, if most of the heatleak is absorbed along the thermal path with the mentioned conductance, even if the PrS itself is much colder. Hence the entropy measurements (see Fig. 1) have considerable uncertainty. But we can conclude, that

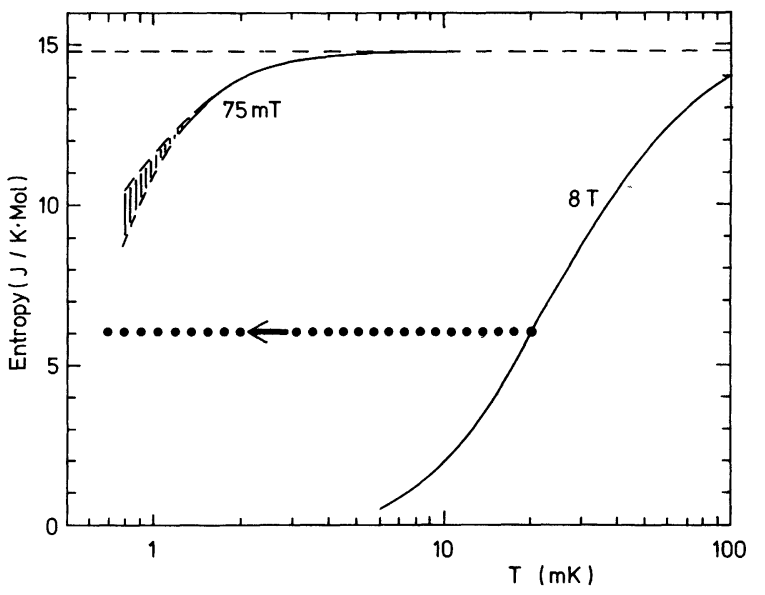

Fig. 1. - Nuclear entropy of PrS. The curve at $8 \mathrm{~T}$ is calculated, the curve at $75 \mathrm{mT}$ measured. Shaded area denotes uncertainty. due to the bad thermal coupling and long internal relaxation. The dotted line shows path during demagnetization. With improved thermal contact minimum temperatures below $0.5 \mathrm{mK}$ are expected.

the nuclear ordering temperature certainly is below $0.8 \mathrm{mK}$, which makes the material interesting as a refrigerant, if the contact problem can be solved and if thin slices provide short thermal path lengths.

\section{References}

[1] Buchal, C., Mueller, R. M., Oversluizen, T. and Pobell, F., Proc. Int. Hakone Symposium, ed. T. Sugawara (publ. by The Physical Society of Japan) 1977, p. 284.

[2] Andres, K. and Darack, S., Physica 86-88B (1977) 1071

[3] Bucher, E., Andres, K., di Salvo, F. J., Maita, J. P., GosSARD, A. C., COOPER, A. S. and Hull, G. W., Jr., Phys. Rev. B11 (1975) 500.
[4] The PrNi ${ }_{5}$ sample was supplied by Pr. K. H. Gschneidner, Jr., Ames Laboratory, Iowa State University, Ames Iowa 50011, U.S.A.

[5] Buchal, C., Hanssen, J., Mueller, R. M. and Pobell, F., Rev. Sci. Instrum. 50 (1978).

[6] Mueller, R. M., Buchal, C., Oversluizen, T. and Pobell, F., Rev. Sci. Instrum. 49 (1978) 515. 